\title{
Enzymatic and Dilute Acid Hydrolyses of Maize Stalk Substrate in Bio-ethanol Production
}

\author{
Kolajo Tolulope Eunice \\ Department of Wood Products Engineering, University of Ibadan, Ibadan, Nigeria \\ Email address: \\ tolukolajo@yahoo.com
}

\section{To cite this article:}

Kolajo Tolulope Eunice. Enzymatic and Dilute Acid Hydrolyses of Maize Stalk Substrate in Bio-ethanol Production. Journal of Energy, Environmental \& Chemical Engineering. Vol. 6, No. 1, 2021, pp. 24-30. doi: 10.11648/j.jeece.20210601.14

Received: February 1, 2021; Accepted: February 9, 2021; Published: February 23, 2021

\begin{abstract}
Biofuels have been identified as suitable in combating climate change as a result of green gas emissions from fossil fuels. Bioethanol is a biofuel from lignocellulosic biomass is considered a viable renewable energy alternative to fossil fuels. However, the recalcitrance of biomass feedstocks due to the presence of lignin, creates a barrier to glucose fermentation. This study compares enzymatic and dilute acid hydrolyses of cellulose substrates obtained from pretreated maize stalk. The cellulose substrates were hydrolysed into glucose using dilute $\mathrm{H}_{2} \mathrm{SO}_{4}$, dilute $\mathrm{HCl}$ and Cellulase enzyme. The glucose obtained was fermented using an active yeast strain (Saccaromyces cerevisae) and then distilled in accordance with ASTM D1078 to obtain bio-ethanol. High Performance Liquid Chromatography (HPLC) was used in quantitative analyses of the bio-ethanol produced while qualitative tests were done based on ASTM D7795-12 for physical tests (density, boiling point, miscibility, non-volatile residues, colour, flammability and distillation range) and chemical tests (Acidity, Alkalinity, Fusel oil, Readily carbonizable substances and readily oxidizable substances). Enzymatic hydrolysis gave a higher glucose yield, while there was no significant difference between hydrolysis using dilute acids. There was significant difference in extraction efficiencies between acid and enzymatic hydrolysis methods. The bio-ethanol produced has similar purity levels with qualitative properties to that of an industrial grade ethanol.
\end{abstract}

Keywords: Cellulose Substrate, Corn Stalk, Hydrolysis, Extraction Efficiencies

\section{Introduction}

Bioethanol is a biofuels that has been introduced as a partial replacement for fossil fuels in countries such as Brazil, India and the USA $[1,2]$. This biofuel has been produced from hydrolysis of starch which has created a competition between energy and food economies [3]. A more sustainable approach is the use of lignocellulosic biomass which basically utilizes wastes. There are several lignocellulosic biomass that have been identified as suitable renewable raw material for use in the biochemical industry; they are cheap and widely available [4-6]. Some of them which are agricultural by-products can be used to produce biofuels. Biofuels obtained from agricultural wastes can help mitigate the negative effects of non-environmental friendly fuels highly utilized globally. The production process in converting these biomass involves a pretreatment to remove lignin, followed by the conversion of complex sugars which are cellulose and hemicellulose into simple sugars such as, glucose and xylose, via hydrolysis. These are then processed into ethanol, xylitol, organic acids, and other substances [7]. Corn stalk is one of the biomass with high potential for profitable use as a raw material for biofuel production, especially in bio-ethanol synthesis.

Corn (Zea mays) also known as maize is largely cultivated globally for consumption and has several residues after harvest. Over 1.4 billion metric tons of maize is produced in the world annually, with the United States, China and Brazil being the leading producers, amassing to about half of the total sum [8]. In Africa, an estimated 3.95 million hectares of land was cultivated and yielded about 6.8 million tonnes of corn in 2016, while about 6.9 million tonnes from 3.8 million hectares was recorded in 2017 [9]. Corn is usually produced for food, while other parts such as the stalks and leaves are residues. First generation biofuel plants produced ethanol from corn grains, and this led to a competition between energy and food economies. The use of lignocelluloses, such as residues from corn production, solves this problem, and 
corn stalk is an agricultural biomass with over 90 percent lignocelluloses left unused after corn harvest. About $0.50 \mathrm{~kg}$ of stalks, are gotten from every $1 \mathrm{~kg}$ of dry corn grains produced [10]. In the United States of America alone, about 250 million tons per year of corn stovers which is made of corn stalks, leaves and corn cobs constitutes 33 percent of solid wastes [11]. Also, a large quantity of the stalks is disposed via burning as reported in [12]; this has a negative effect on the environment. One can, thus infer that the corn stalk is an abundant natural resource, and a rational thing to do will be to utilize it profitably by converting it into useful products. The processing of corn stalk can thus be incorporated into existing first generation biofuel plants that use corn grain as the basic raw material.

Some research in literature has utilized corn stovers which constitute the stalks, leaves and cobs as a single biomass. These constituents, however, have very different chemical and morphological compositions. For example, in an earlier study, Kolajo and Onilude [13] compared the physical and chemical assays of maize stalk fractions and found that corn stalk is an heterogeneous mix of pith and rind fractions with each having different morphology. This in turn will affect the processing of these fractions. Ximenes [14] also posits that a more efficient way of handling corn stalk is in breaking it into fractions before bioprocessing. Further details of the constituents of corn stalks and their utilization can be found in literature [15].

The use of acids for hydrolysis of cellulose materials is well dated [16]. As reported, it has been used on polysaccharide since the $19^{\text {th }}$ century [17]. A list of some acids that have been used to hydrolyze corncob is reported in the work of Huang and Fu [18]. Acids hydrolysis, in general, may lead to formation of organic acid, and this has led to salt formation by reacting with ethanol which is the desired end product [19]. Additionally, they present issues ranging from corrosion, stressful recovery processes, to wastage $[18,20]$. Using dilute acids can reduce some of these problems, but they require very high temperature and pressure, and still, would result in lower percentage yield [21, 22]. Concentrated acids, on the other hand, can give higher yield at lesser temperatures and pressures. However, they can take longer reaction time and it is usually stressful to separate the acid without losing much quantity of the glucose [22]. There are several techniques use to recover the acids from concentrated acids hydrolysis processes with each having its own pros and cons. One recent effective technique to get a balance between the levels of acid concentration is to adopt a two-step hydrolysis process with partial neutralization of the resulting glucose while using optimum conditions for high yield [23].

Enzymatic hydrolysis is the second technique of reducing cellulose material to glucose. For this method, pretreatment has been identified as a major factor that affects the efficiency of the conversion process. Some of the effective pretreatments applied so far have been reviewed [24, 25]. These methods were classified into biological, physical and chemical, with each and all having their respective pros and cons [26]. New pretreatment methods are still being researched anyway, and one of such is the use of microwave [27]. Pretreatment can, however, produce results deviant from one's expectations [28]. So the focus has been to investigate the existing pretreatment method, seeking conditions for better efficiency and reduced cost.

There are a number of reports on the enzymatic hydrolysis of corn and its residual parts, and a few of them is presented in this section. The effect of dilute acids and alkaline mix as a pretreatment method on corn stover components was investigated by Aboagye et al. [29]. Also by pretreating with dilute acid, corn straw was reduced to sugar using cellulase enzymatic hydrolysis [12]. Another study investigated the effect of ball milling, a mechanical operation, on the enzymatic hydrolysis of maize stem [30]. Different methods of pretreatments for corn stover were compared by Kim et al, [31]. They reported that for samples pretreated first with dilute acid and then disk milled gave the highest yield. They showed that the cellulase can be reused. A number of factors and the different type of enzymes used in the hydrolysis of corn stover were highlighted in the report of Aguilar et al [32]. There is however a dearth of information on the quantity of residual lignin that will inhibit cellulose hydroysis.

The aim of this work is to compare the conversion efficiencies of enzymatic and dilute acids hydrolysis of corn substrates (alkaline pretreated corn stalk) and access the variability in associated alcohol levels of the end product (ethanol) Though several works has reported the hydrolysis of corncob, corn stover and corn stillage, a comparison of the two methods for hydrolyzing corn stalk is sparsely reported. With intention to breach this knowledge gap, corn stalk fractions were hydrolysed using enzymes and dilute acids to evaluate glucose yield and conversion efficiency and purity of bioethanol produced.

\section{Materials and Methods}

The cellulose substrate for hydrolysis was obtained from alkaline-pretreated maize stalks. The stalks were obtained from a private farm in Iseyin, Oyo State Nigeria. The stalks were from a 3-months maturation DMR-ESRW species obtained from the Institute of Agricultural Research and Training, IAR\&T, Ibadan, Nigeria. The stalks were first reduced into $25 \mathrm{~mm}$ to $40 \mathrm{~mm}$ length and air-dried prior pretreatment. Pretreatment was done in a chemical reactor designed and fabricated for the purpose [33] using alkaline sulphite at $120^{\circ} \mathrm{C}$ and liquor to solid ratio of $10: 1$. This pretreatment schedule is the optimum obtained from previous work where alkali charges of 14,16 and $18 \% \mathrm{w} / \mathrm{v}$ were used to pretreat maize stalk fractions for 60,90 and 180 minutes in a full factorial experiment [34]. The criteria for optimization were highest cellulose yield with lowest residual lignin.

\subsection{Chemical Composition of Pretreated Substrate}

The chemical composition of the substrate was determined by Goering and Van Soest detergent fibre method of 1970, also adopted by Mertens [35] and Kolajo and Onilude [19]. Lignin content in substrate was determined by grinding the 
air dried substrate to pass $1 \mathrm{~mm}$ screen, weighing in $1 \mathrm{~g}$ of ground substrate in a crucible. $100 \mathrm{ml}$ of neutral detergent solution was added at room temperature into crucible with $0.5 \mathrm{~g}$ of sodium sulphite and some drops of n-octanol. The mixture was heated to boiling and reflux 60 minutes from onset of boiling. It was then filtered and washed three times with boiling water, then twice with cold acetone. The residue was dried for 8 hours at $105^{\circ} \mathrm{C}$ and cooled in desiccators after which it was weighed.

$$
\begin{array}{r}
\text { Neutral Detergent Fibre }(\%)=\frac{W_{3}-\left(W_{1} \times C\right)-\left(W_{5}-W_{4}-D\right)}{W_{2}(N D F)} \\
\text { Acid Detergent Fibre }(\%)=\frac{W_{3}-\left(W_{1} \times C\right)-\left(W_{5}-W_{4}-D\right)}{W_{2}(A D F)} \\
\text { Acid Detergent Lignin }(\%)=\frac{W_{3}-\left(W_{1} \times C\right)-\left(W_{5}-W_{4}-D\right)}{W_{2}(A D L)} \\
\text { Hemicellulose }=N D F-A D F \\
\text { Cellulose }=A D F-A D L
\end{array}
$$

Where:

$\mathrm{W}_{1}=$ Initial capsule weight $(\mathrm{mg})$

$\mathrm{W}_{2}=$ Sample weight (mg)

$\mathrm{W}_{3}=$ Capsule + Residue weight (mg)

$\mathrm{W}_{4}=$ Empty ashing crucible

$\mathrm{W}_{5}=$ Total ash (mg)

$\mathrm{C}=$ Blank Correction for capsule solubility

$\mathrm{D}=$ Capsule ash

\subsection{Enzymatic Cellulose Hydrolysis}

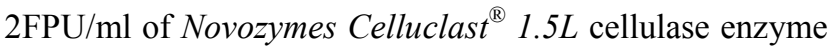
was added to $0.1 \mathrm{~g}$ of each substrate and was incubated at $50^{\circ} \mathrm{C}$ for 24 hours and shaken at $128 \mathrm{rpm}$. The mixture was filtered and glucose concentration was estimated using a spectrophotometer at $340 \mathrm{~nm}$.

\subsection{Acid Cellulose Hydrolysis}

$10 \mathrm{ml}$ each of $0.2 \mathrm{M} \mathrm{H}_{2} \mathrm{SO}_{4}$ and $0.2 \mathrm{M} \mathrm{HCl}$ was added to $0.1 \mathrm{~g}$ of the samples in lightly capped test tubes. The reaction was carried out for 2 hours at $25^{\circ} \mathrm{C}$. The reaction was stopped by neutralizing the acid and slightly reversing the $\mathrm{pH}$ by adding $5 \mathrm{ml}$ volume of concentrated potassium hydroxide solution. The resulting mixture was then filtered. The glucose concentration in the filtrate was measured as in Section 2.2.

The glucose extraction efficiency is derived by:

$$
E(\%)=\frac{M_{\text {glucose }} f_{h}}{M_{\text {initial }} * y_{i}} \times 100
$$

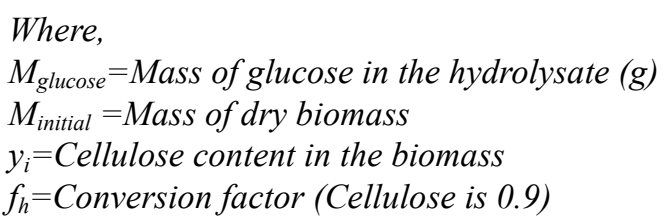

\subsection{Fermentation and Distillation}

Fermentation was carried out in an DNP-9052-1A Thermostat incubator at $37^{\circ} \mathrm{C} .1 .0 \mathrm{~g}$ of an active yeast strain (Saccharomyces cerevisiae) was added to a $100 \mathrm{ml}$ cellulose sample each from the enzymatic and acid hydrolysed samples obtained above. The yeast was gently evenly mixed in, and the mixture was placed in the incubator for 48 hours. Ethanol yield was measured as a ratio of produced ethanol $(\mathrm{g})$ over consumed glucose $(\mathrm{g})$. The ethanol was distilled at $78^{\circ} \mathrm{C}$. Simple batch distillation process was used in accordance with ASTM D86 method for distillation of petroleum products.

\subsection{Quantitative and Qualitative Tests}

Qualitative tests included physical tests (density, boiling point, miscibility with water, odour, non-volatile residues, colour, flammability and distillation range) and chemical tests (Acidity, Alkalinity, Fusel oil, Readily carbonizable substances and readily oxidizable substances). Acidity and alkalinity were determined using ASTM D7795-12 standard while JECFA (1996) standard [36] was adopted for determination of Fusel oil, readily carbonizable and readily oxidizable substances.

Quantitative analysis was conducted using a High Performance Liquid Chromatogram (HPLC) at the Multidisciplinary Research Laboratory, University of Ibadan. The chromatogram obtained the degree of purity, the type and nature of impurities, associated alcohols or formation products present in the bio-ethanol produced.

\section{Results and Discussion}

\subsection{Cellulose Pretreated Substrate}

Table 1. Chemical composition of pretreated substrates.

\begin{tabular}{llllll}
\hline Substrates: & A & B & C & D & Average \\
\hline Cellulose (Glucan) & 61.64 & 62.23 & 60.01 & 63.90 & $61.95 \pm 1.95$ \\
Hemicellulose (Xylan) & 13.37 & 10.4 & 14.9 & 11.01 & $12.42 \pm 2.48$ \\
Lignin & 4.93 & 6.26 & 4.48 & 4.31 & $5.0 \pm 1.26$ \\
\hline
\end{tabular}

*Kolajo and Onilude, 2019

All chemical components examined for the treated samples were found to be lower than the untreated samples (Table 1). This implies that pretreatment affected all three chemical components, with the highest effect seen in lignin removal, which is what the pretreatment targets. The recalcitrance of lignocellulosic biomass to hydrolysis is caused by the 
presence of lignin. Various studies reported cellulose hydrolysis was improved with increasing lignin removal, although differences were reported in the degree of lignin removal needed [37-39]. There is however no complete selective removal of lignin without considerable removal of cellulose. This also means that there is no threshold where the amount of residual lignin does not inhibit cellulose conversion and the rate of hydrolysis.

\subsection{Enzymatic and Dilute Acid Hydrolyses}

Table 2. Enzymatic Hydrolysis and Extraction Efficiency.

\begin{tabular}{|c|c|c|c|c|c|}
\hline Sample & Replicates & Glucose yield & Glucose Yield Average & Extraction Efficiency & Extraction Efficiency Average \\
\hline & & $(\mathrm{mg} / \mathrm{dL})$ & $(\mathrm{mg} / \mathrm{dL})$ & $(\%)$ & $(\%)$ \\
\hline \multirow{3}{*}{ A } & 1 & 396 & \multirow{3}{*}{$395 \pm 1.0$} & 78.33 & \multirow{3}{*}{$78.13 \pm 0.20$} \\
\hline & 2 & 394 & & 77.93 & \\
\hline & 3 & 395 & & 78.13 & \\
\hline \multirow{3}{*}{ B } & 1 & 402 & \multirow{3}{*}{$402 \pm 2.0$} & 79.52 & \multirow{3}{*}{$79.52 \pm 0.40$} \\
\hline & 2 & 404 & & 79.91 & \\
\hline & 3 & 400 & & 79.12 & \\
\hline \multirow[t]{2}{*}{$\mathrm{C}$} & 2 & 395 & \multirow[t]{2}{*}{$395 \pm 1.0$} & 78.13 & \multirow[t]{2}{*}{$78.13 \pm 0.20$} \\
\hline & 3 & 396 & & 78.33 & \\
\hline \multirow{3}{*}{$\mathrm{D}$} & 1 & 398 & \multirow{3}{*}{$400 \pm 2.0$} & 78.73 & \multirow{3}{*}{$79.12 \pm 0.40$} \\
\hline & 2 & 400 & & 79.12 & \\
\hline & 3 & 402 & & 79.52 & \\
\hline
\end{tabular}

Glucose yield ranged from 394 to $404 \mathrm{mg} / \mathrm{dL}$, with an average of $398 \mathrm{mg} / \mathrm{dL}$ for enzymatic hydrolysis. The extraction efficiency ranged from $77.93 \%$ to $79.91 \%$ across the samples (Table 2). These values are comparable with those reported by Xiang et al, (2018). These values may be enhanced with the removal of hemicelluloses from the pretreated biomass as the enzymatic digestion of cellulose has been shown to significantly improve with hemicellulose removal, proving that hemicellulose provides the key barrier to cellulose breakdown by enzymes as also reported by Rafaela et al [39] and Chum et al [40]. Also, the nature of the pretreatment process and its effect on hemicelluloses, affect overall glucose yield and extraction efficiency. When the hemicellulose is modified by the pretreatment process, enzymatic hydrolysis have higher glucose yields [41, 42].

Table 3. Chemical Hydrolysis and Extraction Efficiencies.

\begin{tabular}{|c|c|c|c|c|c|c|c|c|c|}
\hline \multirow[t]{2}{*}{$\begin{array}{l}\text { Sample } \\
\text { Code }\end{array}$} & \multirow[t]{2}{*}{$\begin{array}{l}\text { No. of } \\
\text { Runs }\end{array}$} & \multicolumn{2}{|c|}{ Glucose Yield (mg/dl) } & \multicolumn{2}{|c|}{ Glucose Yield Average (mg/dl) } & \multicolumn{2}{|c|}{$\begin{array}{l}\text { Extraction Efficiency } \\
(\%)\end{array}$} & \multicolumn{2}{|c|}{$\begin{array}{l}\text { Extraction Efficiency Average } \\
(\%)\end{array}$} \\
\hline & & $\mathrm{H}_{2} \mathrm{SO}_{4}$ & HCL & $\mathrm{H}_{2} \mathrm{SO}_{4}$ & HCL & $\mathrm{H}_{2} \mathrm{SO}_{4}$ & HCL & $\mathrm{H}_{2} \mathrm{SO}_{4}$ & HCL \\
\hline \multirow{3}{*}{ A } & 1 & 372 & 374 & \multirow{3}{*}{$374 \pm 2.0$} & \multirow{3}{*}{$374 \pm 1.0$} & 73.58 & 73.98 & & \\
\hline & 2 & 374 & 373 & & & 73.98 & 73.78 & $73.71 \pm 0.4$ & 73.91 \\
\hline & 3 & 372 & 374 & & & 73.58 & 73.98 & & \\
\hline \multirow{3}{*}{ B } & 1 & 375 & 376 & \multirow{3}{*}{$375 \pm 1.0$} & \multirow{3}{*}{$376 \pm 1.0$} & 74.18 & 74.37 & & \\
\hline & 2 & 374 & 376 & & & 74.37 & 74.37 & $74.18 \pm 0.2$ & 74.31 \\
\hline & 3 & 376 & 375 & & & 73.98 & 74.18 & & \\
\hline \multirow{3}{*}{$\mathrm{C}$} & 1 & 370 & 372 & \multirow{3}{*}{$371 \pm 2.0$} & \multirow{3}{*}{$372 \pm 1.0$} & 73.19 & 73.58 & & \\
\hline & 2 & 372 & 370 & & & 73.58 & 73.19 & $73.32 \pm 0.26$ & 73.52 \\
\hline & 3 & 370 & 373 & & & 73.19 & 73.78 & & \\
\hline \multirow{2}{*}{$\mathrm{D}$} & 1 & 375 & 375 & \multirow{2}{*}{$375 \pm 1.0$} & \multirow{2}{*}{$376 \pm 1.0$} & 74.18 & 74.18 & & \\
\hline & 3 & 376 & 376 & & & 74.37 & 74.37 & & \\
\hline
\end{tabular}

The results obtained for glucose yield and the extraction efficiencies are similar for both dilute $\mathrm{H}_{2} \mathrm{SO}_{4}$ and $\mathrm{HCl}$ hydrolysis (Table 3). The highest glucose yield was $376 \mathrm{mg} / \mathrm{dL}$, with an average of $373 \mathrm{mg} / \mathrm{dL}$ for both dilute $\mathrm{H}_{2} \mathrm{SO}_{4}$ and dilute $\mathrm{HCl}$ hydrolyses. Extraction efficiencies across the samples ranged from $73.19 \%$ to $74.37 \%$ for both hydrolyses methods. The extraction efficiency of $73.32 \%$ to $74.31 \%$ obtained in this study is higher than $71.9 \%$ obtained by Hamzeh et al [43] who hydrolysed cellulose obtained from pine wood using dilute $\mathrm{H}_{2} \mathrm{SO}_{4}$. Extraction efficiencies from enzymatic hydrolysis are higher than for dilute acids. Hamzeh et al [43] also obtained higher extraction efficiency from enzymatic hydrolysis. Dilute acid hydrolysis performed better with starch hydrolysis than cellulose hydrolysis [43].

Enzymatic hydrolysis $(398.00 \pm 3.49)$ have a significantly higher glucose yield compared to $\mathrm{H}_{2} \mathrm{SO}_{4}(373.91 \pm 2.06)$ and $\mathrm{HCl}$ hydrolysis $(374.16 \pm 1.89)(p<.005)$. However, although $\mathrm{HCl}(78.73 \pm .69)$ have slightly higher glucose yield than 
$\mathrm{H}_{2} \mathrm{SO}_{4}(73.96 \pm .41)$, T-test shows this difference is not significant $(\mathrm{t}(22)=-.31)$ at $95 \%$ confidence level. Comparing extraction efficiency between $\mathrm{H}_{2} \mathrm{SO}_{4}(73.96 \pm .41)$ and $\mathrm{HCl}$
(74.01 \pm .37$)$, there is no statistical significance at $95 \%$ confidence level $(\mathrm{t}(22)=-.31, p>.05)$ (Table 4).

Table 4. Summary one-way ANOVA showing the differences in glucose yield between acid and enzymatic hydrolyses.

\begin{tabular}{|c|c|c|c|c|c|c|}
\hline & \multirow{2}{*}{$\mathbf{N}$} & \multirow{2}{*}{ Mean \pm S. D } & \multirow{2}{*}{ Std. Error } & \multicolumn{3}{|c|}{ Scheffe post hoc Analysis } \\
\hline & & & & 1 & 2 & 3 \\
\hline Enzymatic & 12 & $398.00 \pm 3.49^{b}$ & 1.00755 & - & $24.08^{*}$ & $23.83 *$ \\
\hline $\mathrm{H}_{2} \mathrm{SO}_{4}$ & 12 & $373.91 \pm 2.06^{\mathrm{a}}$ & 0.59618 & & & -0.25 \\
\hline $\mathrm{HCl}$ & 12 & $374.16 \pm 1.89^{\mathrm{a}}$ & 0.54818 & & & \\
\hline Total & 36 & $382.03 \pm 11.73$ & 1.95444 & \multicolumn{3}{|c|}{ * The mean difference is significant at the 0.05 level. } \\
\hline
\end{tabular}

Mean with the same letter are not statistical different at 0.05 level of significance

\subsection{Qualitative and Quantitative Tests}

Qualitative test

The results of qualitative tests carried out on the bioethanol samples produced shows the physical properties of the sample compared with laboratory grade ethanol. The bioethanol produced was a clear colourless liquid which boiled at $78^{\circ} \mathrm{C}$. It had a density of $0.81 \mathrm{~g} / \mathrm{ml}$. It had complete miscibility with water, with no haze or turbidity developed. It also had a sweet odour characteristic of ethanol. On evaporation, no residue was left and the distillation range was between $78^{\circ} \mathrm{C}$ to $79^{\circ} \mathrm{C}$. In all, the physical properties of the bio-ethanol compared well with laboratory grade ethanol. The bio-ethanol exhibits chemical traits very similar to the laboratory grade ethanol (Table 5) in test for acidity, alkalinity, fusel oil, readily carbonizable substances and readily oxidizable substances.

Table 5. Chemical properties of sample compared with laboratory grade ethanol.

\begin{tabular}{lll}
\hline Chemical Test & Laboratory grade ethanol* & Result \\
\hline Acidity & Not more than $1.0 \mathrm{ml}$ restored the pink colour & Less than $1.0 \mathrm{ml}$ was required to restore the pink colour \\
Alkalinity & Not more than $2.0 \mathrm{ml}$ restored the red colour & Less than $2.0 \mathrm{ml}$ was required to restore the red colour \\
Fusel oil & $\begin{array}{l}\text { No foreign odour is perceptible as the last traces of ethanol } \\
\text { evaporates }\end{array}$ & No perceptible odour as the sample evaporated \\
Readily oxidizable substances & $\begin{array}{l}\text { Mixture is colourless or has no more than either the acid or } \\
\text { sample before mixture }\end{array}$ & Colourless samples \\
Readily carbonizable- substances & Pink colour of remains & Pink colour was restored \\
\hline
\end{tabular}

*Analar ${ }^{\circledR}$ chemicals.

Quantitative tests

Table 6. Gas-Liquid Chromatography of the Bio-ethanol produced from Enzymatic hydrolysis.

\begin{tabular}{|c|c|c|c|c|c|c|c|}
\hline Peak \# & Component Name & Time [mins] & Are $[u V * s e c]$ & Height [uV] & Area [\%] & Raw Amount & Adjusted Amount \\
\hline 1 & Ethanol & 5.739 & 58482.29 & 6318.99 & 23.40 & 60.3323 & 60.3323 \\
\hline 2 & & 6.094 & 128396.12 & 3914.50 & 51.38 & 0.1284 & 0.1284 \\
\hline \multirow[t]{2}{*}{3} & & 6.500 & 63039.21 & 3062.01 & 25.22 & 0.0630 & 0.0630 \\
\hline & & & 249917.62 & 13295.51 & 100.00 & 60.5237 & 60.5237 \\
\hline
\end{tabular}

Table 7. Gas-Liquid Chromatography of the Bio-ethanol produced from dilute acid hydrolysis.

\begin{tabular}{|c|c|c|c|c|c|c|c|}
\hline Peak \# & Component Name & Time [mins] & Area $\left[u V^{*}\right.$ sec $]$ & Height [uV] & Area [\%] & Raw Amount & Adjusted Amount \\
\hline 1 & \multirow[t]{6}{*}{ Ethanol } & 5.671 & 65695.97 & 8039.82 & 23.47 & 61.5581 & 61.5581 \\
\hline 2 & & 5.844 & 31162.66 & 3615.22 & 11.13 & 0.0312 & 0.0312 \\
\hline 3 & & 6.092 & 93037.29 & 3593.76 & 33.24 & 0.0930 & 0.0930 \\
\hline 4 & & 6.504 & 84168.62 & 3508.23 & 30.07 & 0.0842 & 0.0842 \\
\hline \multirow[t]{2}{*}{5} & & 7.742 & 5840.56 & 394.53 & 2.09 & 0.0058 & 0.0058 \\
\hline & & & 279905.10 & 19151.57 & 100.00 & 61.7723 & 61.7723 \\
\hline
\end{tabular}

The bio-ethanol produced from enzymatic hydrolysis shows a percentage purity of $60.52 \%$, with some associated alcohols accounting for about $1 \%$ and water accounting for the remaining parts (Table 6) while the ethanol produced from dilute acid hydrolysis had a percentage purity of $61.55 \% \mathrm{v} / \mathrm{v}$ ethanol in water, with traces of associated alcohols accounting for less than $1 \%$ of the product and water made up about $37.45 \%$ of the mix (Table 7). This ethanol concentration is lower than 88.7-82.5\% ethanol obtained by Ademiluyi and Mepba [44] from ethanol produced from maize starch. However, a higher ethanol concentration can be achieved by further distillation using fractionating columns or dehydration. 


\section{Conclusion}

Chemical compositions of pretreated cellulose substrate were determined before hydrolysis. Enzymatic and dilute acid hydrolysis schedules were successful, indicating sufficient biomass delignification. Enzymatic hydrolysis of corn stalk substrates yielded a higher glucose volume and extraction efficiency than dilute acid hydrolyses, using $\mathrm{HCl}$ and $\mathrm{H}_{2} \mathrm{SO}_{4}$. The bio-ethanol produced exhibits all the physical characteristics associated with ethanol produced from other sources. Acidity, alkalinity, fusel oil, readily carbonizable and readily oxidizable substances exhibited similar traits to laboratory grade ethanol.

\section{Acknowledgements}

This work was supported by the Petroleum Technology Development Fund (PTDF) of the Federal Republic of Nigeria and The Postgraduate School, University of Ibadan, Nigeria.

\section{References}

[1] Morales M, Quintero J, Conejeros R, Aroca G. Life cycle assessment of lignocellulosic bioethanol: environmental impacts and energy balance. Renew Sustain Energy Rev 2015; 42: 1349-61.

[2] Soam S, Kapoor M, Kumar R, Borjesson P, Gupta RP, Tuli DK. Global warming potential and energy analysis of second generation ethanol production from rice straw in India. Appl Energy 2016; 184: 353-64.

[3] Agostinho F, Bertaglia ABB, Almeida C, Giannetti BF. Influence of cellulase enzyme production on the energeticenvironmental performance of lignocellulosic ethanol. Ecol Model 2015; 3 15: 46-56.

[4] Williams CL, Westover TL, Emerson RM, Tumuluru JS, Li C. 2015. Sources of biomass feedstock variability and the potential impact on biofuels production. Bioenergy Res 9 (1): 1-14. doi: 10.1007/s12155-015-9694-y.

[5] Pavlečić M, Rezić T, Ivančić Šantek M, Horvat P, Šantek B. 2017. Bioethanol production from raw sugar beet cossettes in horizontal rotating tubular bioreactor. Bioprocess Biosyst Eng. 2017; 40 (11): 1679-88. 10.1007/s00449-017-1823-x.

[6] Arijana Bušić, Nenad Marđetko, Semjon Kundas, Galina Morzak, Halina Belskaya, Mirela Ivančić Šantek, Draženka Komes, Srđan Novak, and Božidar Šantek, 2018. Bioethanol Production from Renewable Raw Materials and Its Separation and Purification: A Review. Food Technol Biotechnol. 2018 Sep; 56 (3): 289-311. doi: 10.17113/ftb.56.03.18.5546.

[7] Xia, L. M. \&. S. X. L., 2004. High-yield cellulase production by Trichoderma reesei ZU-02 on corn cob residues. Bioresource Technology, Volume 91, p. 259-262.

[8] Shahbandeh, M., 2020. Corn production worldwide 2018/2019, by country. [Online] Available at: https://www.statista.com/statistics/254292/global-cornproduction-by-country/ [Accessed 23 May 2020].

[9] Vincent A, Buhari Y, Buhari S (2018) Farmers differ on expected maize output. Daily trust newspapers report,
Published on Feb 18, 2018. Media Trust Limited. https://www.dailytrust.com.ng/farmers-differ-on-expectedmaize-output.html. Accessed 21 Mar 2019.

[10] Sokhansanj S, Turhollow A, Cushman J, Cundiff J (2002) Engineering aspects of collecting maize stalk for bioenergy.

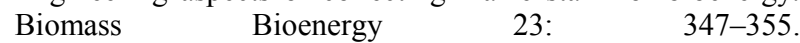
https://doi.org/10.1016/S0961-9534(02)00063-6.

[11] ScienceDaily, 2006. Corn Waste Potentially More Than Ethanol -- ScienceDaily. [Online] Available at: https://www.sciencedaily.com/releases/2006/07/06071909142 1. htm [Accessed 22 May 2020].

[12] Chen, M., Zhao, J. \& Xia, L., 2008. Enzymatic hydrolysis of maize straw polysaccharides for the production of reducing sugars. Carbohydrate Polymers, Volume 71, p. 411-415.

[13] Kolajo T. E. and Onilude M. A. 2019. Physical and Chemical assays of maize stalk fractions for ethanol production. Energy, Ecology and Environment. https://doi.org/10.1007/s40974019-00110-z.

[14] Ximenes E (2011) Dividing corn stover makes ethanol conversion more efficient. Purdue University News Service. Accessed 11/12/2013.

[15] Chen, H., 2015. Integrated industrial lignocellulose biorefinery chains. 1st ed. s.1.: Woodhead Publishing, Elsevier Ltd..

[16] Nanjing Forestry Institute, 1961. Plant Hydrolysis Technology,, Beijing, 1st edition: Agricultural Press.

[17] Yoon, S.-Y., Han, S.-H. \& Shin, S.-J., 2014. The effect of hemicelluloses and lignin on acid hydrolysis of cellulose. Energy, Volume 2014, pp. 1-6.

[18] Huang, Y.-B. and Fu, Y., 2013. Hydrolysis of cellulose to glucose by solid acid catalysts. Green Chem., Volume 15, pp. 1095-1011.

[19] Cho, D. et al., 2010. Enhanced ethanol production from deacetylated yellow poplar acid hydrolysate by Pichia stipitis. Bioresour Technol, Volume 101, p. 4947.

[20] Torget, R. W., Kim, J. S. \& Lee, Y. Y., 2000. Fundamental Aspects of Dilute Acid Hydrolysis/Fractionation Kinetics of Hardwood Carbohydrates. 1. Cellulose Hydrolysis. Ind. Eng. Chem. Res., Volume 39, pp. 2817-2825.

[21] Iranmahboob, J., Nadim, F. \& and Monemi, S., 2002. Optimizing acid-hydrolysis: a critical step for production of ethanol from mixed wood chips. Biomass Bioenergy, Volume 22 , p. 401-404.

[22] Hamelinck, C., Hooijdonk, G. \& van Faaij, A., 2005. Ethanol from lignocellulosic biomass: techno-economic performance in short-, middle- and long-term. Biomass Bioenergy, Volume 28 , p. $384-410$

[23] Chang, J. K.-W. et al., 2018. Two-Step Thermochemical Cellulose Hydrolysis With Partial Neutralization for Glucose Production. Front. Chem., 6 (117), pp. 1-11.

[24] Mood, S. et al., 2013. Lignocellulosic biomass to bioethanol, a comprehensive review with a focus on pretreatment. Renew. Sust. Energ. Rev., Volume 27, pp. 77-99.

[25] Balat, M., 2011. Production of bioethanol from lignocellulosic materials via the biochemical chemical pathway: a review. Energ. Convers. Manage, Volume 52, p. 858-875. 
[26] Conde-Mejíaa, C., Jiménez-Gutiérreza, A. \& El-Halwagi, M., 2012. A comparison of pretreatment methods for bioethanol production from lignocellulosic materials. Process Safety and Environmental Protection, Volume 90, pp. 189-202.

[27] Mikulski, D., Kłosowski, G., Menka, A. \& Koim-Puchowska, B., 2019. Microwave-assisted pretreatment of maize distillery stillage with the use of dilute sulfuric acid in the production of cellulosic ethanol. Bioresource Technology, Volume 278, p. 318-328.

[28] Golkowska, K. \& Greger, M., 2013. Anaerobic digestion of maize and cellulose under thermophilic and mesophilic conditions A comparative study. biomass and bioenergy, Volume 56, pp. 545-554.

[29] Aboagye, D. et al., 2017. Glucose recovery from different corn stover fractions using dilute acid and alkaline pretreatment techniques. Journal of Ecology and Environment, 41 (26), pp. 1-11.

[30] Sipponena, i. H., Laaksoa, S. \& Baumberger, S., 2014. Impact of ball milling on maize (Zea mays L.) stem structural components and on enzymatic hydrolysis of carbohydrates. Industrial Crops and Products, Volume 61, pp. 130-136.

[31] Kim, S. M. et al., 2016. Improvement of sugar yields from corn stover using sequential hot water pretreatment and disk milling. Bioresource Technology, Volume 216, p. 706-713.

[32] Aguilar, D. L. et al., 2018. Operational Strategies for Enzymatic Hydrolysis in a Biorefinery. In: S. Kumar \& R. K. Sani, eds. Biorefining of Biomass to Biofuels, Biofuel and Biorefinery Technologies. AG: Springer International Publishing, pp. 223-248.

[33] Kolajo, T. E and Onilude, M. A. 2016. Design and Construction of a Low Temperature Chemical Reactor for Biomass Pre-Treatment. International Journal of Engineering Research \& Technology (IJERT) ISSN: 2278-0181 IJERTV5IS010221 Vol. 5 Issue 01, January-2016.

[34] Kolajo T. E. 2020. Predictive modeling and optimization of alkaline sulphite and sodium hydroxide pretreatments of maize stalk fractions in the production of bio-ethanol. Proceedings of the 2020 International Virtual Convention of Society of Wood Science and Technology, July 12-15, Slovenia. Pp 42-53.

[35] Mertens, D. R. (1992). Critical conditions in determining detergent fibre. Proceedings of NFTA Forage Analysis Workshop. Denver, CO. p C1-C8.

[36] Joint Expert Committee on Food Additive (JECFA). (1996). Combined Compendium of Food Additive Specifications. Analytical methods, test and procedures and laboratory solutions used and referenced in the food additive specifications. Food and Agriculture Organization of the United Nations.

[37] Yang, B., A. Boussaid, S. D. Mansfield, D. J. Gregg and J. N. Saddler. (2002). Fast and efficient alkaline peroxide treatment to enhance the enzymatic digestibility of steam-exploded softwood substrates. Biotechnology Bioengineering 77 (6), 678-684.

[38] Xiang Li Mi Li Yunqiao Pu Mark Thies Yi Zheng 2018. Inhibitory effects of lignin on enzymatic hydrolysis: The role of lignin chemistry and molecular weight. Renewable Energy. Volume 123, August 2018, Pages 664-674.

[39] Rafaela I. S. Ladeira Ázar, Sidnei Emilio Bordignon-Junior, Craig Laufer, Jordan Specht, Drew Ferrier and Daehwan Kim. 2020. Effect of Lignin Content on Cellulolytic Saccharification of Liquid Hot Water Pretreated Sugarcane Bagasse. Molecules. 25, 623.

[40] Chum, H. L., Johnson D. K. and Black S. K. (1998). Organosolv pretreatment for enzymatic hydrolysis of poplar. I. Enzyme hydrolysis of cellulosic residues. Biotechnology and Bioengineering. 31, 643-649.

[41] Vlasenko, E. Y., H. Ding, J. M. Labavitch and S. P. Shoemaker (1997). Enzymatic hydrolysis of pre-treated rice straw. Bioresource Technology. 59 (2 \& 3), 109-119.

[42] Teymouri, F., L. Laureano-Perez, H. Alizadeh, and B. E. Dale. (2005). "Optimization of the Ammonia Fibre Explosion (AFEX) Treatment Parameters for Enzymatic Hydrolysis of Maize Stalk.” Bioresource Technology 96 (18): 2014-18.

[43] Hamzeh, H., K. Keikhosro, Z. Hamid and J. T. Mohammad. (2010). Simultaneous Pretreatment of Lignocellulose and Hydrolysis of Starch Mixtures to Sugars. "Lignocellulose and Starch". Bio-Resources 5 (4), 2457-2468.

[44] Ademiluyi, F. T. and H. D. Mepba. (2013). Yield and Properties of Ethanol Biofuel produced from Different Whole Cassava Flours. International Scholarly Research Notices. ISRN Biotechnology Article ID 916481. 